\title{
Flood simulation using EPA SWMM 5.1 on small catchment urban drainage system
}

\author{
Junaidi $^{1, *}$, Lusi Marta Ermalizar $^{1}$ and Ahmad Junaidi $^{1}$ \\ ${ }^{1}$ Water Resource Engineering, Civil Engineering Department, Andalas University, 25163 Padang, Indonesia
}

\begin{abstract}
The area around Sungai Sapih District Hospital of Padang is often flooded. The existing drainage system inadequate to accommodate the increasing of drainage loads due to the changing land use in the area. In order to evaluate the drainage system in the study area, EPA SWMM version 5.1 was used to develop the simulation model. This model was able to calculate the quantity and quality of surface runoff from each catchment area, flow discharge, flow depth, and water quality in each pipeline and drainage channel during the simulation period. The data used in this research are maps of land use, rain data, and drainage channel dimensions. Hourly time series rain data was used and as this was not directly unavailable at the train station at the study site, it was calculated by constructing a rain estimation hyetograph from the 5-year Intensity-Duration-Frequency (IDF) curve using the Alternating Block Method (ABM). After all EPA SWMM 5.1 parameters were specified and inputted, simulation with four simulation scenarios was performed based on the present and the future possible land use and the change of dimension and shape of the drainage channel. The first scenario produced 18 flooding occurrences, the second; 20, the third and fourth; 14 . Of note were the 14 flooding points in the third and fourth scenario despite the shape and dimension of the drain used being in accordance with the detail of drainage planning of Sungai Sapih area according to the city master plan for 2010-2030. This shows that the drainage planning design (DED) for Sungai Sapih District Public Hospital is insufficient to contain the drainage load of the area, either now or in the future.
\end{abstract}

\section{Introduction}

Padang city is prone to floods. National Disaster Management Agency (BNPB) data shows the city of Padang includes areas that are at high-risk for flood disasters [1]. Reference [2] shows have identified 23 flood events in the period 2011-2013 which he categorized into three types; stagnant floods, flash floods, and floods due to peak tides. An inadequate drainage system is one of the main causes of flooding in Padang. One area of the city that is often flooded is around Sungai Sapih hospital (Figure 1). One of the reasons for this is because this area is directly affected by the 2011 relocation of Padang City Government Center from Bagindo Aziz Chan Road to Air Pacah which is adjacent to Sungai Sapih District Public Hospital. Before 2011, the Sungai Sapih area was surrounded by vegetation such as rice and corn fields and grass and some housing. But by 2016 this land use was changing with increasing development of infrastructure, housing complexes and development of public facilities including a university and expansion of the Sungai Sapih hospital itself. Changes in land use inevitably lead to changes in the quantity of surface flow in existing drainage systems [3].
Zaharfi et al. [4] state the cause of flooding in this area is due to the garbage that accumulates in the drainage channels, the flow of flood waters from upstream and poor maintenance of the drainage channels. Therefore, it is necessary to maintain drainage channels that are large enough for all the rainwater that collects in the area.

SWMM is a rainfall-runoff model used for simulating the quantity and quality of surface runoff from urban areas. Surface runoff is generated from rain catchment areas. The surface runoff load is then channeled through pipelines, open drains, storage systems, and pumps [5].

The EPA SWMM.5.1 program can model and analyze the quantity and problems of urban runoff. EPA SWMM.5.1 shows the quantity produced in each subwatershed, water discharge, and flow depth. By using EPA SWMM, conditions occurring in the field can be modeled by including parameters recorded under field conditions. The collection of technical data including channel length, channel dimension, and channel slope is done by direct observation in the field [6].

\footnotetext{
Corresponding author: junaidi@eng.unand.ac.id
} 


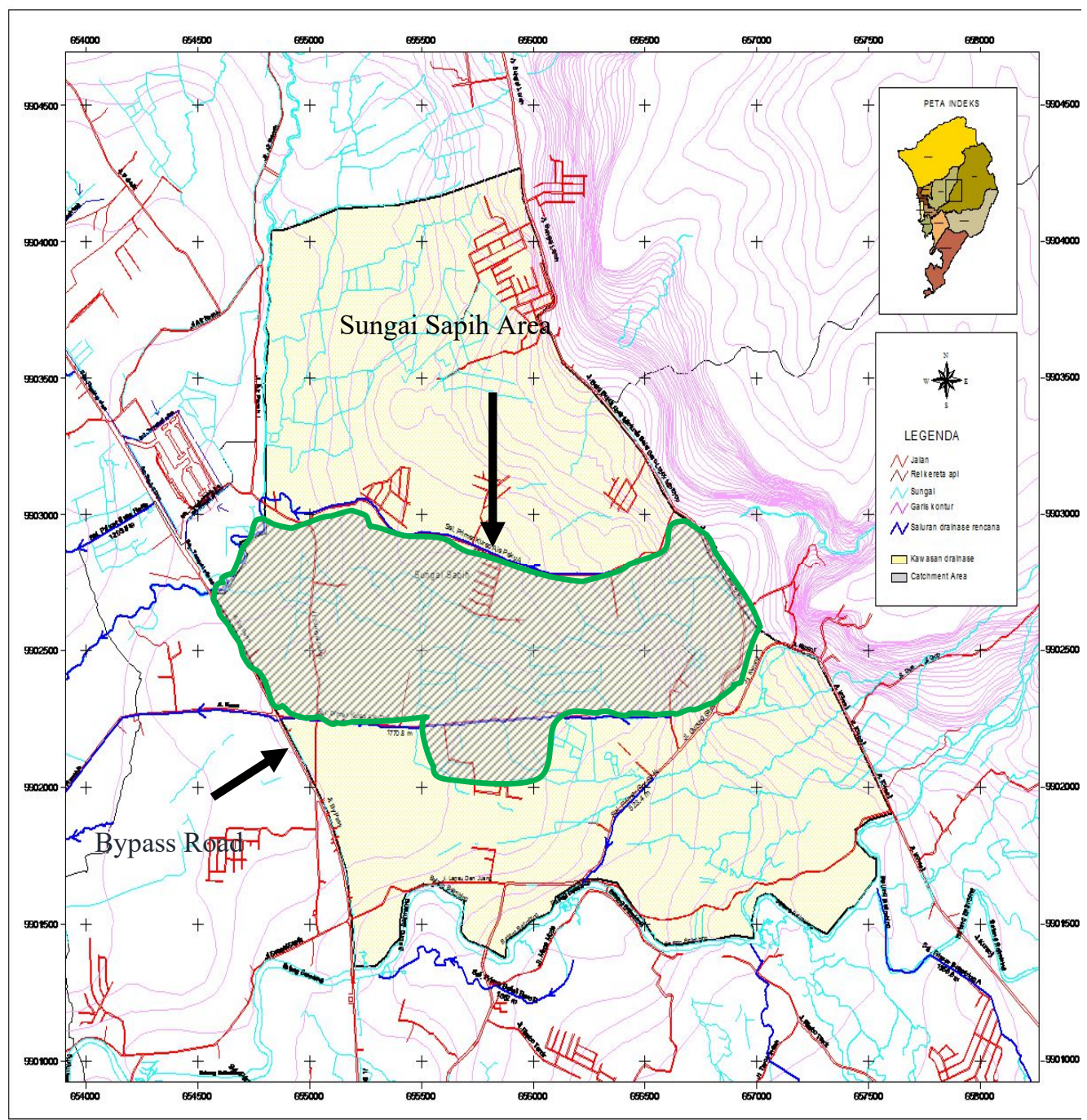

Fig. 1. Location of Sungai Sapih Area (source: Detailed Engineering Drainage (DED) of Padang, Public Works Service 2013)

\section{Research methods}

This research is divided into three parts; data collection, data processing and output in the form of conclusions and recommendations from research results.

\subsection{Data collection and processing}

Land used data used was from the 2016 land use map (Figure 2) and the 2010-2030 Padang land use master plan map for the Sungai Sapih area (Figure 3) [7]. These maps show the percentage of the area impervious to water which formed one input parameter for the EPA SWMM 5.1 model.

The application of this SWMM model can be used in planning of dimensions of water catchment facilities for flood control such as retarding basins, mapping of flooded areas and natural drainage systems, planning of regulatory strategies to minimize drainage flow through evaluation of the influence of inflow and infiltration on the flow discharge of the drainage system, and identifying sources of pollutant transport.
Using these tools and the data from the study described above this research assesses the capacity of the drainage network of Sungai Sapih area to contain flooding using EPA SWMM version 5.1.

Rainfall data used was the maximum daily rainfall data from Gunung Sarik station in Padang for the last 24 years [8]. This rainfall data is required for hydrological analysis for the subsequent 5 years period. Calculation of rainfall intensity used the Mononobe Method. This is because the available rain data is daily. The rainfall intensity was calculated in the form of IDF curves which were used to prepare a Hyetograph using the Alternating Block Method (ABM) ([9] - [10]). This is done because an hourly data series was used as the input in the EPA SWMM simulation.

The drainage channel dimension data used was the 2013 dimension measurement data and detailed engineering drainage data (DED) of the 2013 hospital area drainage channels in accordance with the 20102030 master land use plan for the region [11]. 


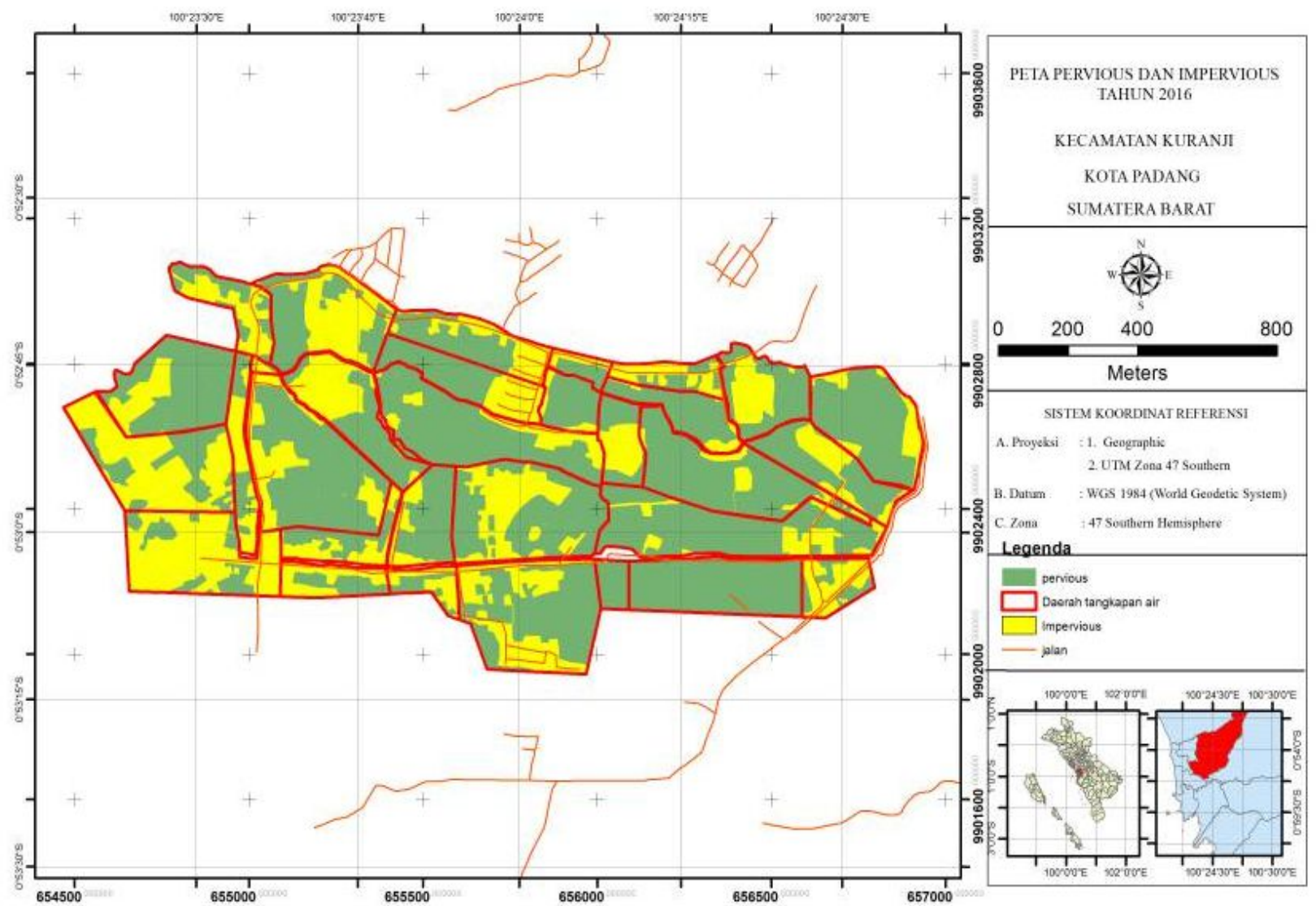

Fig. 2. Sungai Sapih's land use in 2016 (source : Google Earth, access at $23^{\text {rd }}$ November 2016)

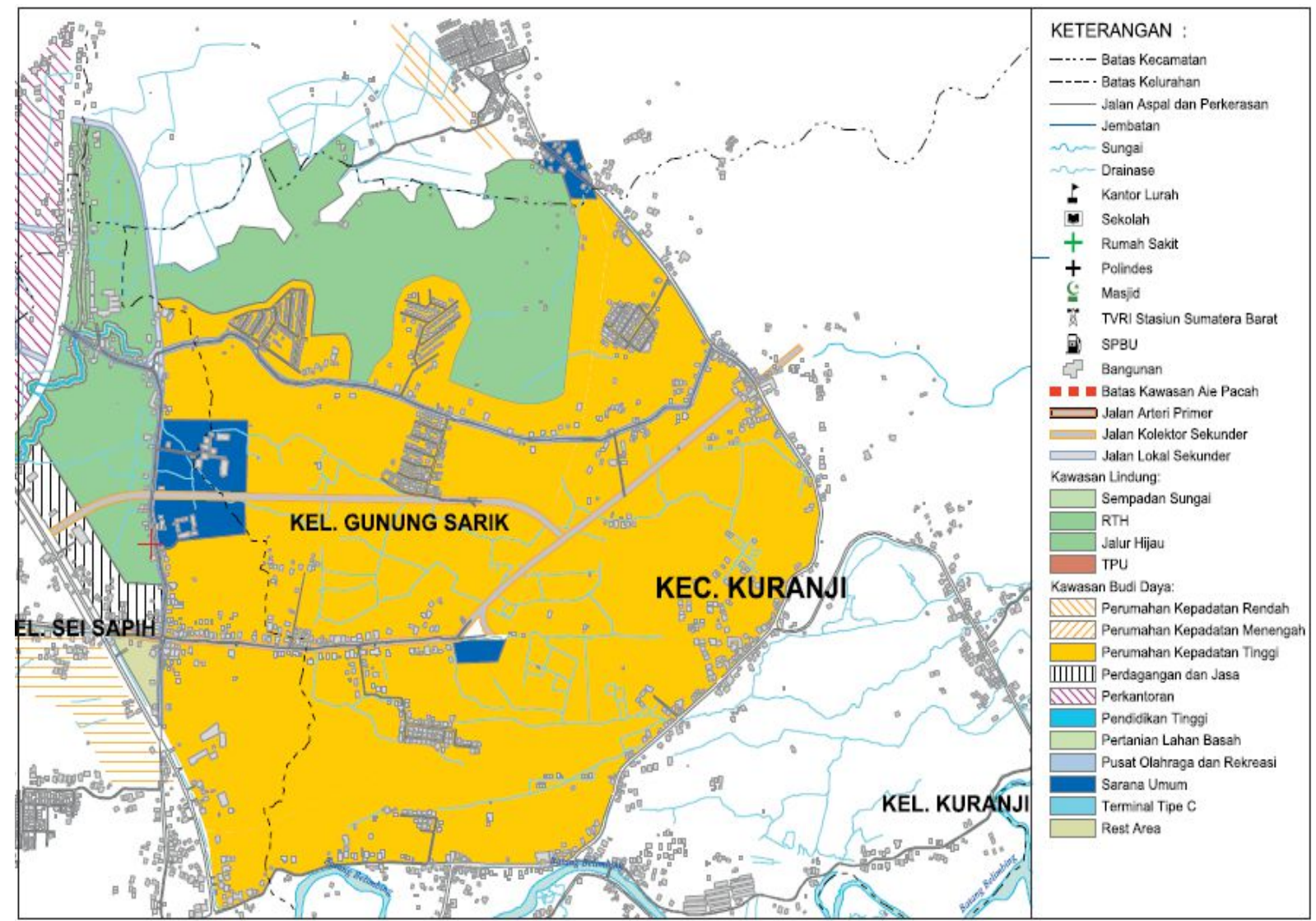

Fig. 3. The planning of Sungai Sapih's land use in 2030 (source: Padang Master Plan 2010-2030) 


\subsection{Simulation of drainage network with EPA} SWMM 5.1.

Simulation scenarios can be seen in Table 1 below

Table 1. Simulation scenarios

\begin{tabular}{|c|c|c|c|c|}
\hline \multirow[b]{2}{*}{ 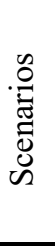 } & \multicolumn{2}{|c|}{ Land Use } & \multicolumn{2}{|c|}{ Drainage Dimension } \\
\hline & $\begin{array}{l}\text { Existin } \\
g \\
(2016)\end{array}$ & $\begin{array}{l}\text { Future } \\
\text { (Padang } \\
\text { Master } \\
\text { Plan 2010- } \\
\text { 2030) }\end{array}$ & $\begin{array}{l}\text { Existin } \\
g \\
(2013)\end{array}$ & $\begin{array}{l}\text { Future } \\
\text { (DED } \\
\text { Drainge in } \\
2013 \text { ) }\end{array}$ \\
\hline 1 & $\sqrt{ }$ & & $\sqrt{ }$ & \\
\hline 2 & & $\sqrt{ }$ & $\sqrt{ }$ & \\
\hline 3 & $\sqrt{ }$ & & & $\sqrt{ }$ \\
\hline 4 & & $\sqrt{ }$ & & $\sqrt{ }$ \\
\hline
\end{tabular}

\subsection{Analysis of Simulation Results}

After all, data had been collected and processed, and the simulations conducted the results of the four scenarios were analyzed.

\section{Results and discussion}

\subsection{Hydrological analysis}

Annual maximum rainfall data from each year from 1987 to 2011 was determined using Gunung Sarik station data and tabulated as shown in Table 2.

Table 2. Annual maximum rainfall

\begin{tabular}{|c|c|c|c|c|c|}
\hline No & Year & $\begin{array}{c}\text { Annual } \\
\text { maximum } \\
\text { rainfall. } \\
(\mathrm{mm})\end{array}$ & No & Year & $\begin{array}{c}\text { Annual } \\
\text { maximu } \\
\mathrm{m} \\
\text { rainfall. } \\
(\mathrm{mm})\end{array}$ \\
\hline 1 & 1987 & 218,00 & 13 & 1999 & 194,00 \\
\hline 2 & 1988 & 127,50 & 14 & 2000 & 242,00 \\
\hline 3 & 1989 & 121,00 & 15 & 2001 & 204,00 \\
\hline 4 & 1990 & 111,00 & 16 & 2002 & 290,00 \\
\hline 5 & 1991 & 155,00 & 17 & 2003 & 229,00 \\
\hline 6 & 1992 & 172,00 & 18 & 2004 & 207,00 \\
\hline 7 & 1993 & 113,00 & 19 & 2005 & 236,00 \\
\hline 8 & 1994 & 143,00 & 20 & 2007 & 114,00 \\
\hline 9 & 1995 & 195,00 & 21 & 2008 & 89,00 \\
\hline 10 & 1996 & 196,00 & 22 & 2009 & 82,00 \\
\hline 11 & 1997 & 98,00 & 23 & 2010 & 215,00 \\
\hline 12 & 1998 & 260,00 & 24 & 2011 & 155,00 \\
\hline
\end{tabular}

\subsection{Rain intensity and distribution}

Figure 4 shows the IDF curve used to estimate rain intensity values at the site of the study. The Hyetograph using this estimated rainfall intensity for a five-year period is presented in Figure 5.

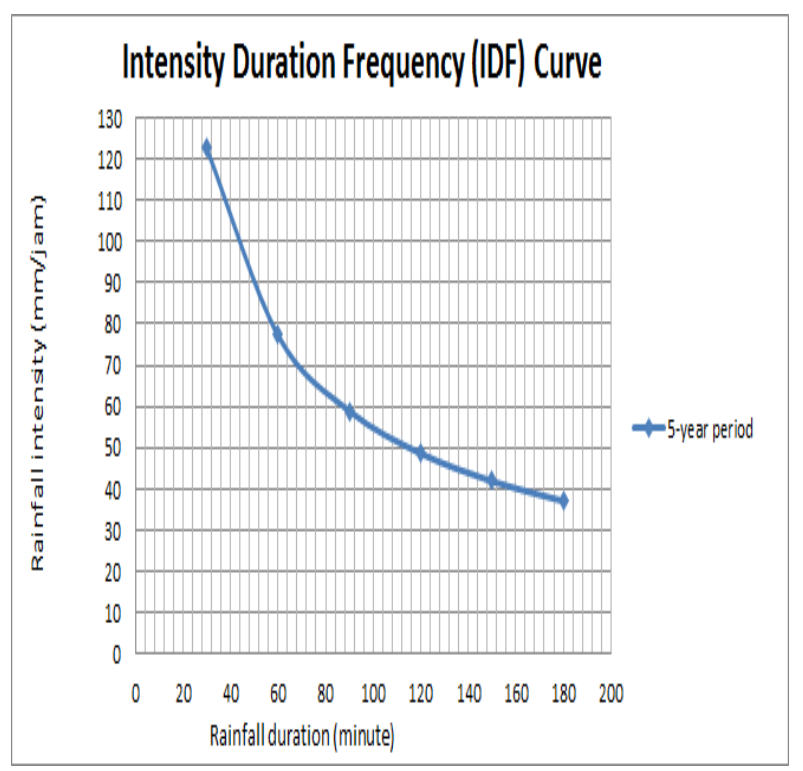

Fig. 4. IDF Curve for the five-year period

\section{Hyetograph rainfallestimation}

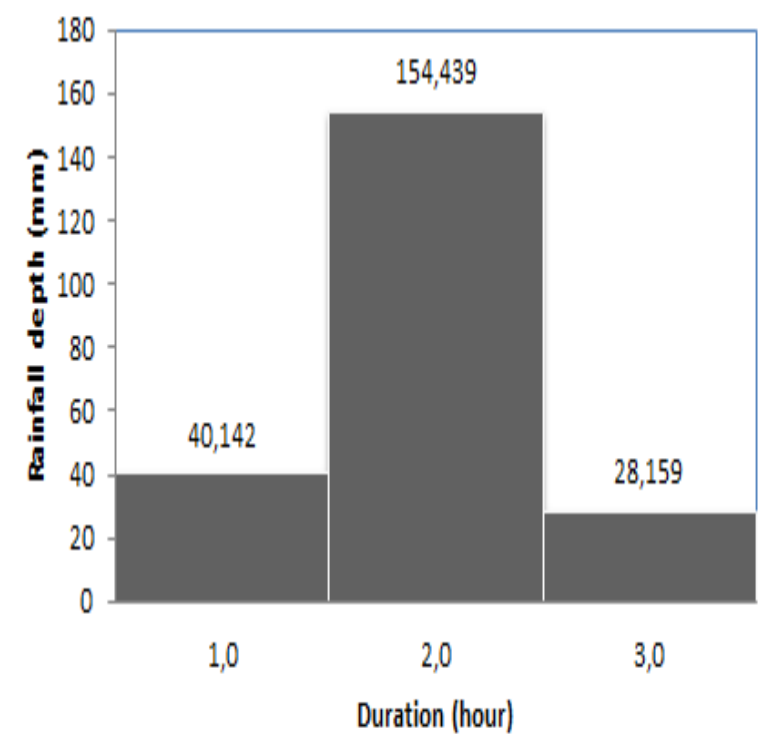

Fig. 5. Hyetograph rainfall estimation

\subsection{Simulation of drainage network with EPA SWMM 5.1.}

In this study, the parameters inputted were from subcatchment, junction, conduit, and rain gage and the subcatchment area was divided into 27 sub-catchments (Figure 6), 22 junctions, 3 outs, and 24 conduits 


\subsection{The result of drainage network modeling with EPA SWMM 5.1}

\subsubsection{Scenario 1 (Existing land use - Existing drainage)}

In this scenario, the quality of the simulation results is quite good, the continuity error for surface runoff and flow routing are -0.084 and $-0.409 \%$ respectively. This is much better than the values established by Rossman [12] indicating a simulation is of low quality if the continuity error is $>10 \%$.

\subsubsection{Scenario 2 (Future land use - Existing drainage)}

From the simulation, the continuity errors for surface runoff and flow routing are -0.086 and - 0,400\% respectively.

Figure 8 shows 20 channels overflow after 3 hours. This is due to channel dimensions that are insufficient to accommodate runoff flow.

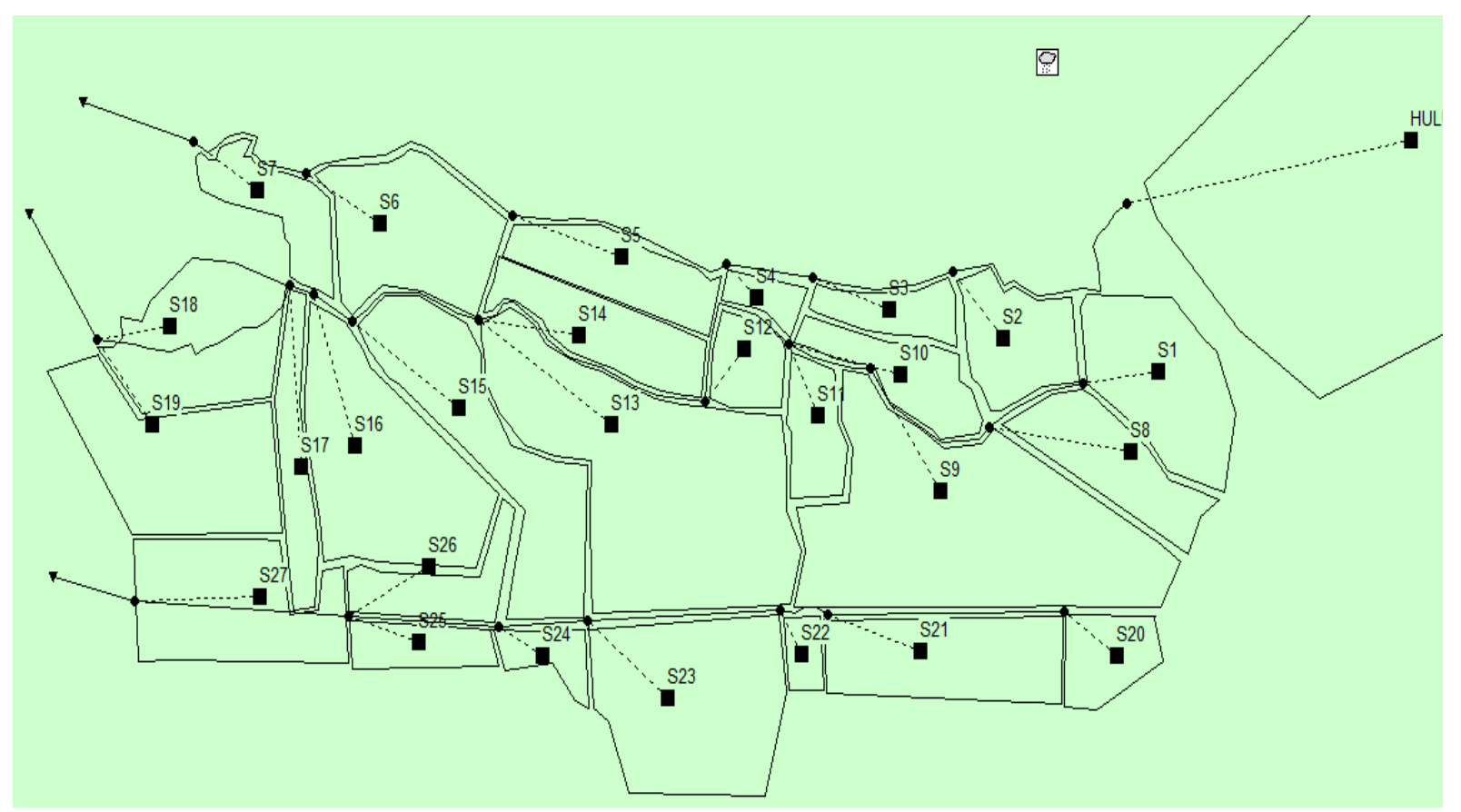

Fig. 6. Subcatchments at drainage networks of Sungai Sapih Area

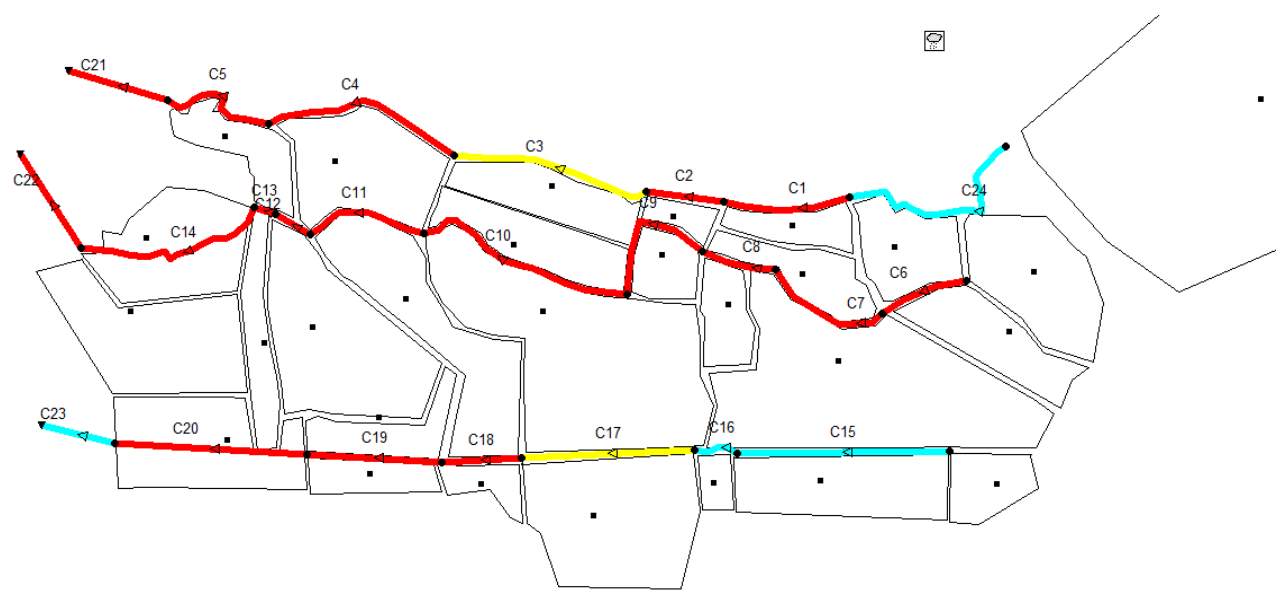

Note :

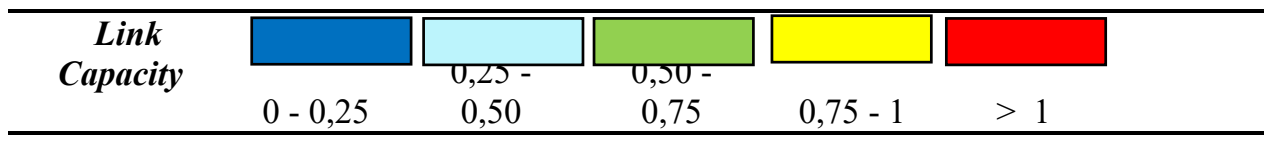

Fig. 7. Overflowing conduits in scenario 1 


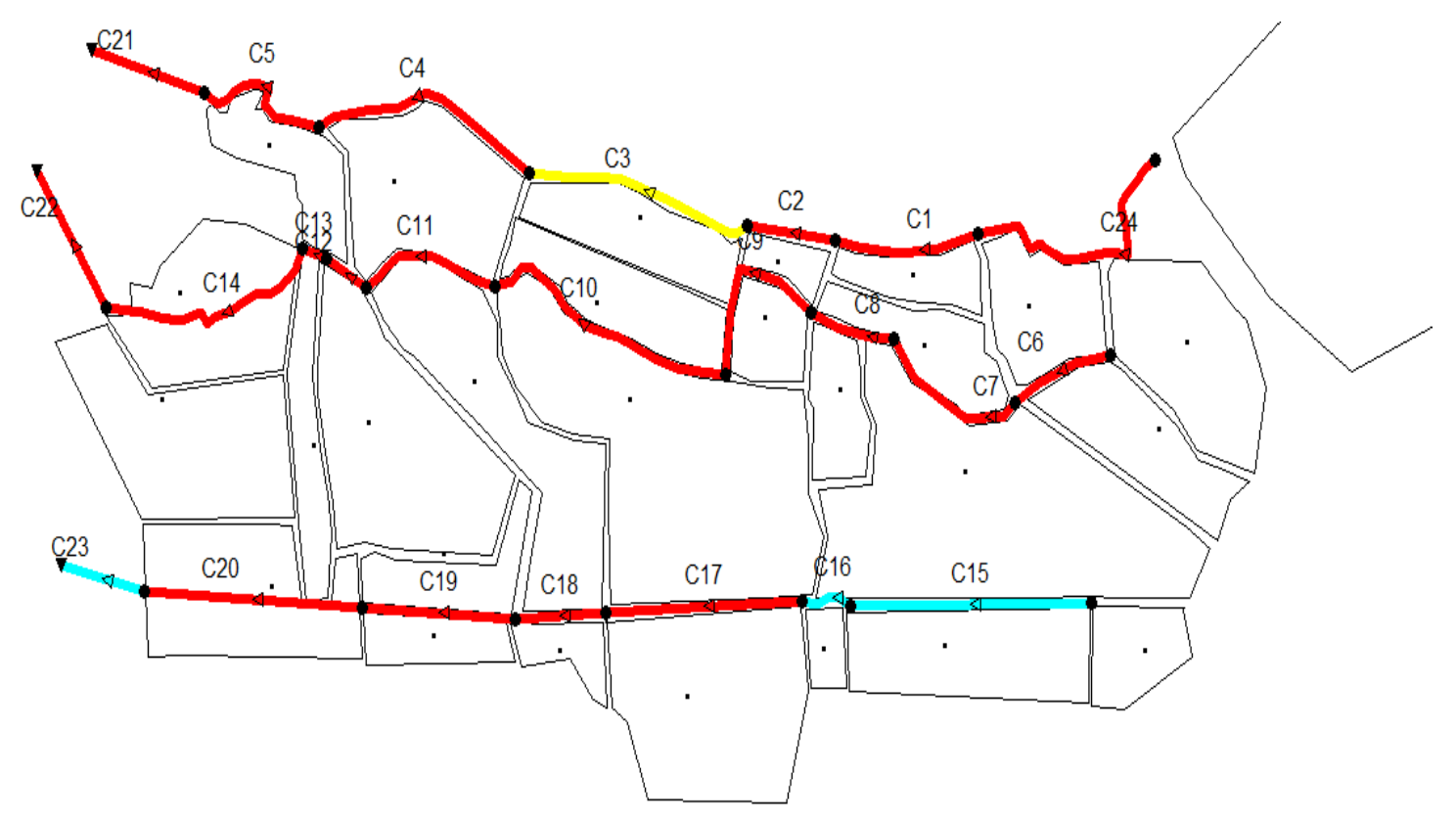

Note :

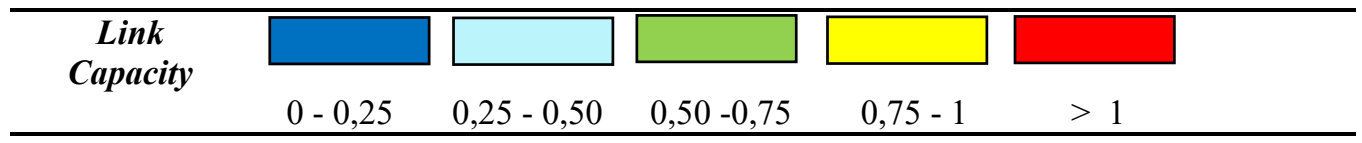

Fig. 8. Overflowing conduits in scenario 2

\subsubsection{Scenario 3 (Existing land use - Future drainage)}

Continuity errors for surface runoff and flow tracing are -0.084 and $-0.356 \%$ respectively.

Figure 9 shows 14 channels overflowed after 3 hours. This is due to channel dimensions that cannot accommodate runoff flow.

\subsubsection{Scenario 4 (Future land use- Future drainage)}

For this simulation continuity errors for surface runoff and flow, routing was equal to $-0,086$ and $-0,333 \%$ respectively indicating a good enough simulation quality.

Note :
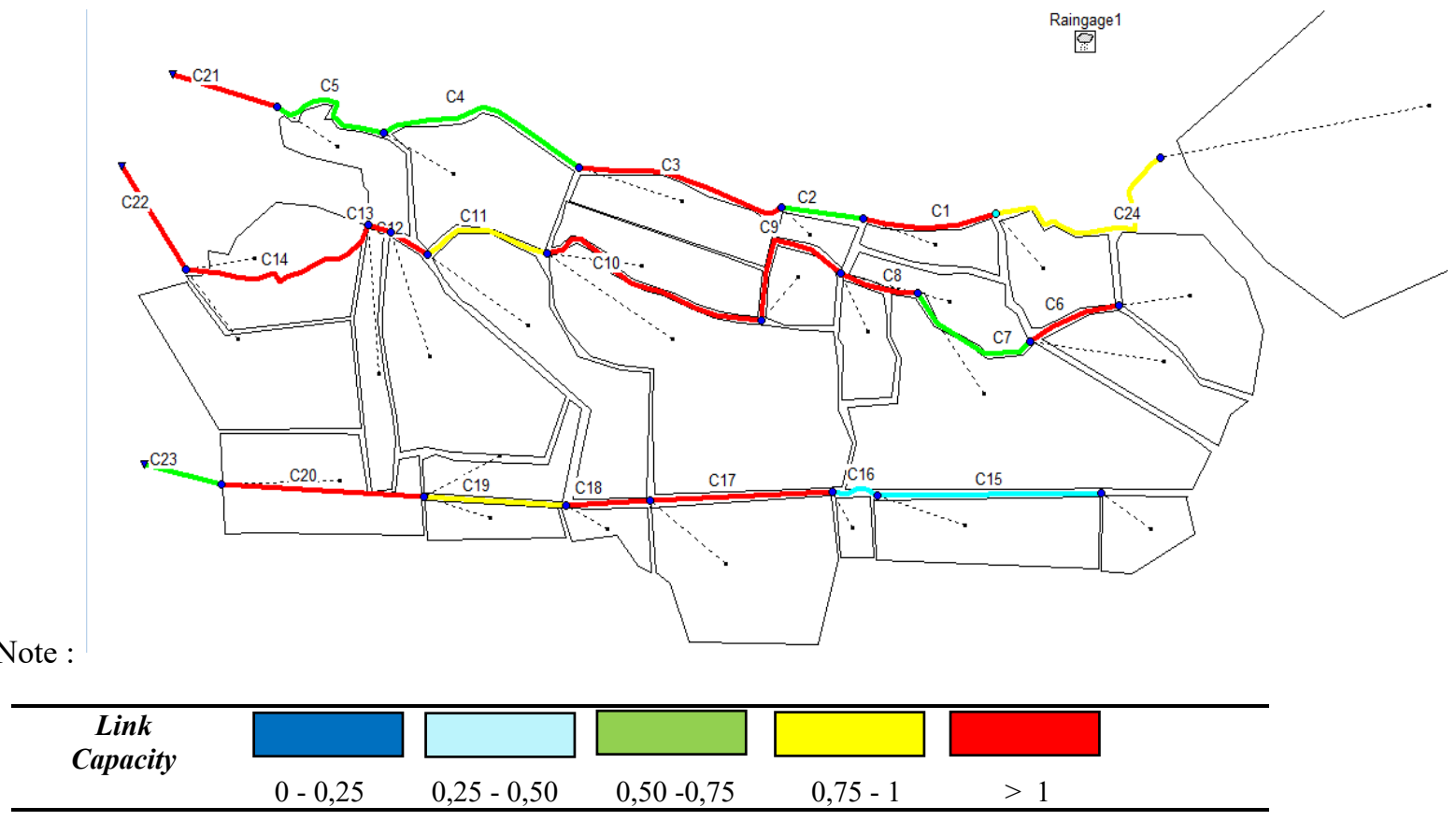

Fig. 9. Overflowing conduits in scenario 
Note :
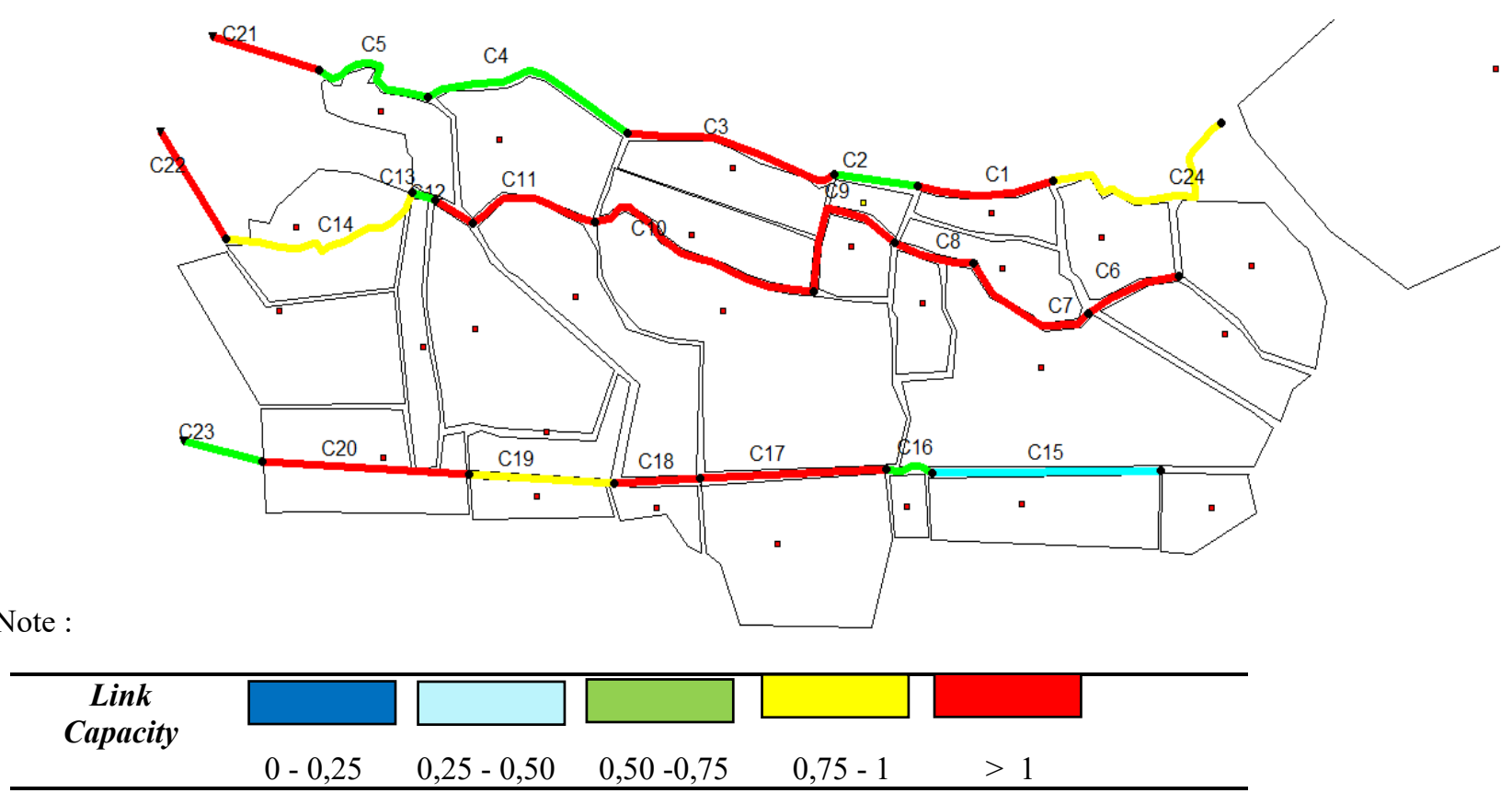

Fig. 10. Overflowing conduits in scenario 4

Figure 10 shows 14 channels overflow after 3 hours. This is due to channel dimensions that are insufficient to accommodate runoff flow.

\subsubsection{Analysis of EPA SWMM 5.1 drainage network simulation results}

A review of the results of drainage network modeling with SWMM provided a comparison of flood duration at each junction between the four scenarios. This can be seen in Table 3 and Figure 11. (See Fig.12. for the location of junction parameter at drainage networks of Sungai Sapih area)

Table 3. Comparison of flood hour

\begin{tabular}{|r|l|c|c|c|c|}
\hline \multirow{2}{*}{ NO } & \multirow{2}{*}{$\begin{array}{c}\text { JUNCTIO } \\
(\mathrm{J})\end{array}$} & \multicolumn{4}{|c|}{ COMPARISON OF FLOOD } \\
\cline { 3 - 6 } & & $\mathrm{SC} 1$ & $\mathrm{SC} 2$ & $\mathrm{SC} 3$ & $\mathrm{SC} 4$ \\
\hline 1 & $\mathrm{~J} 1$ & 2,33 & 2,33 & 1,88 & 1,9 \\
\hline 2 & $\mathrm{~J} 2$ & 2,78 & 2,78 & & \\
\hline 3 & $\mathrm{J3}$ & & & 2,02 & 2 \\
\hline 4 & $\mathrm{J4}$ & 1,48 & 1,6 & & \\
\hline 5 & $\mathrm{~J} 5$ & 2,43 & 2,22 & & \\
\hline 6 & $\mathrm{J6}$ & 4,92 & 4,95 & 4,92 & 4,83 \\
\hline 7 & $\mathrm{J7}$ & 6 & 3,93 & 2,33 & 2,2 \\
\hline 8 & $\mathrm{~J} 8$ & 0,68 & 1,32 & & 0,62 \\
\hline 9 & $\mathrm{~J} 9$ & 2,43 & 2,98 & 1,82 & 2,42 \\
\hline 10 & $\mathrm{~J} 10$ & 10,65 & 6,97 & 2,38 & 2,67 \\
\hline
\end{tabular}

\begin{tabular}{|c|c|c|c|c|c|}
\hline 11 & $\mathrm{~J} 11$ & 1,08 & 1,38 & 4,57 & 3,98 \\
\hline 12 & $\mathrm{~J} 12$ & 1,58 & 2 & & 0,75 \\
\hline 13 & $\mathrm{~J} 13$ & 3,27 & 3,08 & 0,95 & 1,98 \\
\hline 14 & $\mathrm{~J} 14 \mathrm{~A}$ & 3,7 & 3,35 & 0,4 & \\
\hline 15 & $\mathrm{~J} 14 \mathrm{~B}$ & 5,7 & 4,32 & 1,28 & \\
\hline 16 & $\mathrm{~J} 15$ & 0,82 & 1,35 & 3,1 & 3 \\
\hline 17 & $\mathrm{~J} 16$ & & & & \\
\hline 18 & $\mathrm{~J} 17$ & & & & \\
\hline 19 & $\mathrm{~J} 18$ & & 0,9 & 0,38 & 1,12 \\
\hline 20 & J19 & 2,72 & 2,65 & 1 & 1,55 \\
\hline 21 & $\mathrm{~J} 20$ & 1,62 & 1,67 & & \\
\hline 22 & $\mathrm{~J} 21$ & 3,35 & 3,18 & 2,07 & 2,18 \\
\hline 23 & $\begin{array}{l}\text { J_PRIME } \\
\text { R }\end{array}$ & & 0,92 & & \\
\hline \multicolumn{2}{|c|}{$\begin{array}{l}\text { Average flood } \\
\text { duration }\end{array}$} & 3,20 & 2,69 & 2,08 & 2,23 \\
\hline \multicolumn{2}{|c|}{$\begin{array}{l}\text { Number of flood } \\
\text { points }\end{array}$} & 18 & 20 & 14 & 14 \\
\hline
\end{tabular}

Note :

SC : Simulation scenario

$\square$ : Flooding did not occur

: Flooding occurred 


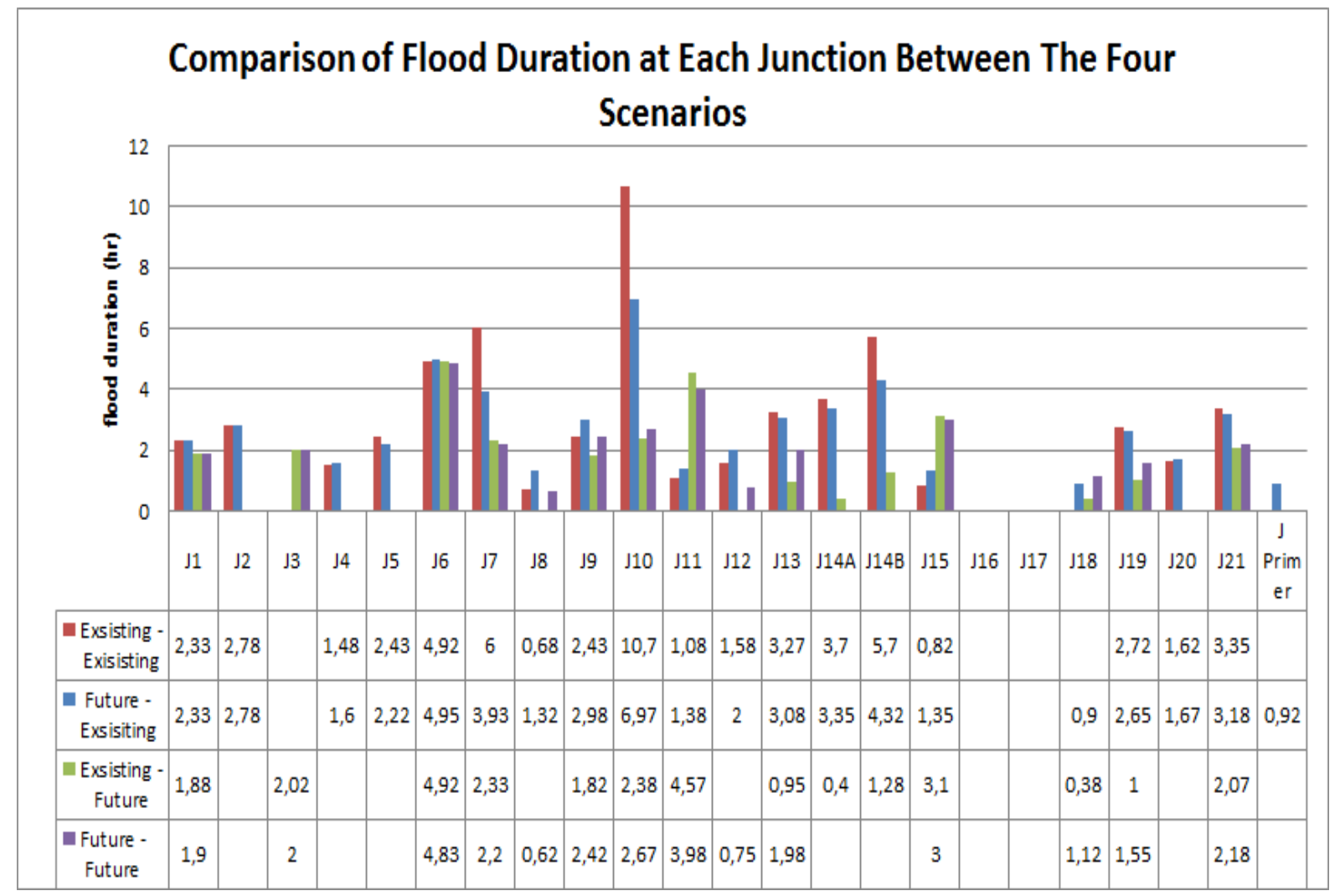

Fig. 11. Comparison of flood duration at each junction between the four scenarios

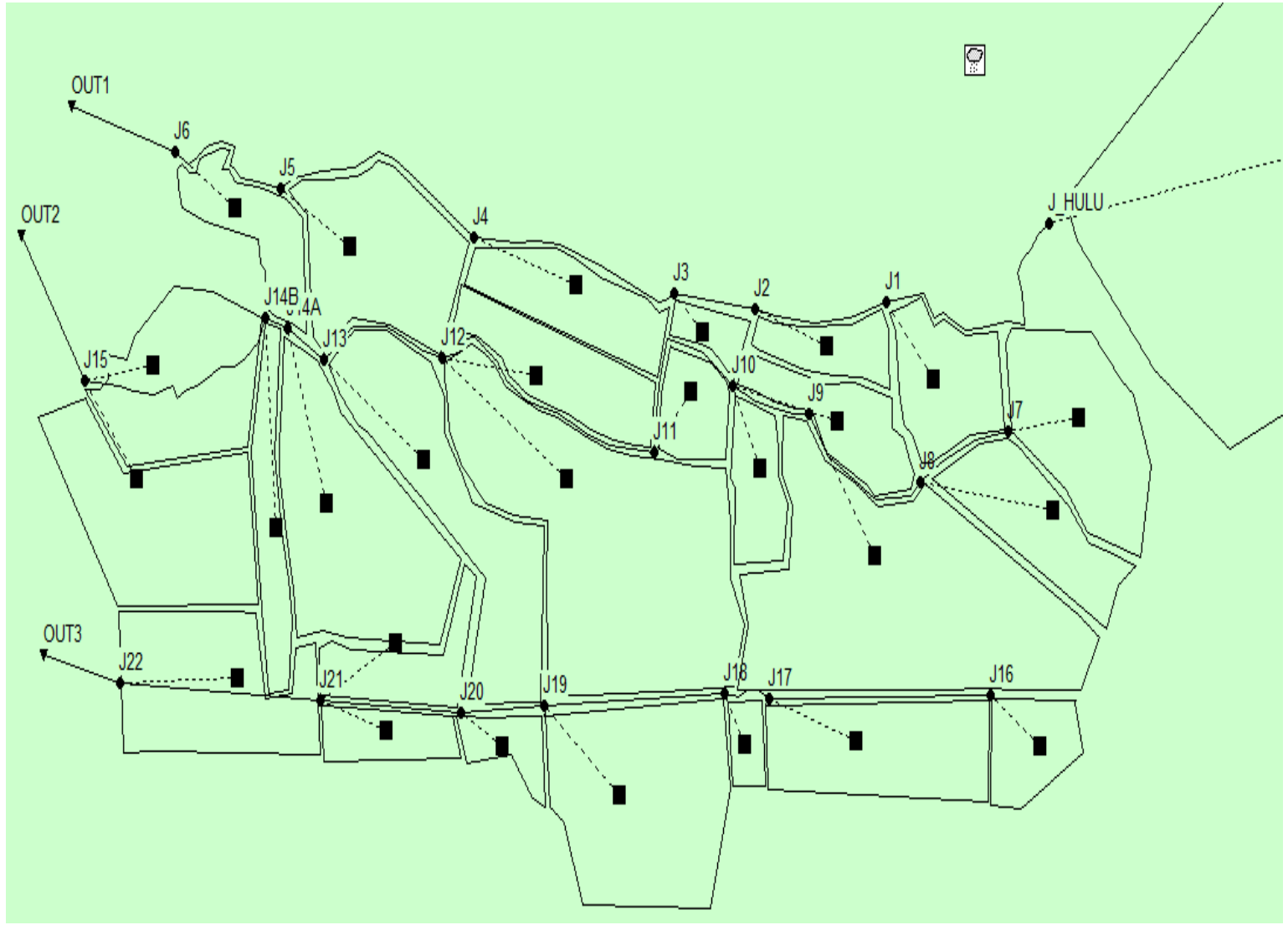

Fig. 12. Location of juntion parameter at drainage networks of Sungai Sapih area 
From the tables above, it has been seen between scenario 1 and 2 that there is a change in the number of flood points. This is because of the change of land use in the Sungai Sapih area that not followed by changes in the dimensions of the drainage channel. So the previous channel cannot accommodate large runoff discharge due to land use changes.

In scenario 3 and 4 , there are 14 flood points which happened, in fact, that the shape and dimension of drainage used the drainage planning of RSUD Sungai Sapih for the condition according to RTRW 2010-2030. Therefore, it is better to review the drainage detail engineering design of RSUD Sungai Sapih area to minimize the flooding points that have been occurred in accordance with EPA SWMM 5.1 simulations result.

\section{Conclusions}

From the results of the research, it can be concluded that: - The existing drainage channels of Sungai Sapih area is insufficient to accommodate predicted runoff, either for existing, or future land use as the number of flood points from the simulation with existing land use was 18 and with future land use 20.

- If the existing drainage channels were to be upgraded in accordance with 2013 Detailed Engineering Drainage (DED) plans they would still not be sufficient to accommodate runoff discharge for existing or future land use. The simulations indicated 14 flood points for each land use scenario.

This study should be continued using more recent rainfall and drainage data to allow for changes that have occurred since 2011. The effectiveness of the use of polders to reduce flood points could be considered in subsequent research.

We would like to thank the Engineering Faculty of Andalas University supported this work under contract number 020/UN.16.09.D/PL/2018 and also to Public Works Service and other stakeholders to provide data for the research.

\section{References}

1. BNPB, "Indonesia 2013 Disaster Prone Index", Jakarta, 2014, from http://bnpb.go.id/uploads/publication/612/IRBI\%20 2013 Resize.pdf

2. B. Hidayat, "Understanding Flood Disaster in Padang City with News Article Content Analysis", Andalas University, 9 things, (2014)

3. Y. Winata, N. Djali, Khaidir I, Analysis of Drainage Channels in Padang City Government Center, Aie Pacah, Bung Hatta University, (2014).

4. Zaharfi R, Samah M, Farni I, Drainage Planning of RSUD area and Villa Gading II \& III Complex Sungai Sapih Kuranji District, Padang City, Bung Hatta University, 2014.

5. Lewis A. Rossman, Storm Water Management Model User's Manual Version 5.1, National Risk Management Research Laboratory Office Of Research And Development U.S. Environmental Protection Agency, (2015)
6. AA. Prasetyo, Evaluation of Drainage Channels in Jasem Village, Sidoarjo Regency Using Environmental Protection Agency Storm Water Management Model (EPA SWM) 5.1, State University of Malang, Malang, (2014)

7. Padang City Regional Regulation No. 4 of 2014 concerning the Padang City Spatial Plan for 20102030 Padang City

8. PSDA (1988-2012), Rainfall Data Publication 1987 - 2011, Department of Water Resources Management, West Sumatra Province, Padang.

9. R. Nurhidayah, "The pattern of distribution of rain at the time of day in Sub Das Alang", Sebelas Maret University, Surakarta, (2010)

10. B. Triatmodjo, HidrologiTapap, Beta Offset Publisher, Yogyakarta, (2009)

11. Public Works Service, DED (Detail Engineering Design) Planning Padang City Drainage, Sungai Sapih Hospital Area, (2013)

12. L. Rossman, W.C. Huber, Storm Water Management Model Reference Manual Volume I Hydrology (Revised), Cincinnati (US) EPA United States Environmental Agency, (2016)

13. E. Supriyani, M. Bisri, V. Generous. Study on the Development of an Environmental-Based Urban Drainage System (Case Study of the Magersari Drainage System in Mojokerto City), Water Resources Engineering Journal, Volume 3, Number 2, December 2012, pp. 112-121, (2012)

14. Suripin, Sustainable Urban Drainage System, Publisher Andi, Yogyakarta, (2004)

15. E. Aditya, "Evaluation of Drainage Channels with Epa Swmm 5.1 Models at Griya Telaga Permai Housing, Depok, West Java", Bandung Institute of Agriculture, Bandung, (2015) 